\title{
Correction to: Strategic Assessment of Lisbon's Accessibility and Mobility Problems from an Equity Perspective
}

\section{Camila Soares Henrique Fontenele Garcia ${ }^{1}$ - Rosário Macário ${ }^{1}$. Ezequiel Dantas de Araújo Girão Menezes ${ }^{2}$. Carlos Felipe Grangeiro Loureiro ${ }^{2}$}

Published online: 2 July 2021

(C) Springer Science+Business Media, LLC, part of Springer Nature 2021

\section{Correction: Netw Spat Econ (2018) 18:415-439 https://doi.org/10.1007/s11067-018-9391-4}

The author wish to correct the second author name from Maria do Rosário Maurício Ribeiro Macário to Rosário Macário as usually used in her other publications. The original article has been corrected.

Publisher's note Springer Nature remains neutral with regard to jurisdictional claims in published maps and institutional affiliations.

The online version of the original article can be found at https://doi.org/10.1007/s11067-018-9391-4

Camila Soares Henrique Fontenele Garcia

camilagarcia@tecnico.ulisboa.pt

Rosário Macário

rosariomacario@tecnico.ulisboa.pt

Ezequiel Dantas de Araújo Girão Menezes

ezequieldantas@gmail.com

Carlos Felipe Grangeiro Loureiro

felipe@det.ufc.br

1 CERIS, IST, Universidade de Lisboa, Av. Rovisco Pais, 1049-001 Lisbon, Portugal

2 DET, Universidade Federal do Ceará, Campus do Pici - Bloco 703, Fortaleza CE 60.440-900, Brazil 